\title{
THE AUTHENTIC ASSESSMENT TO MEASURE STUDENTS' ENGLISH PRODUCTIVE SKILLS BASED ON 2013 CURRICULUM
}

\author{
Dwi Rukmini \\ Lenggahing Asri Dwi Eko Saputri \\ English Department, Semarang State University, Indonesia \\ wiwidwirukmini@yahoo.com', lenggahingasri@yahoo.com²
}

First received: 4 October 2016

Final proof received: 29 September 2017

\begin{abstract}
In 2013, the Indonesian Ministry of Education and Culture published the 2013 Curriculum which demands teachers to implement authentic assessment as the method of assessing the students' competence. There were three areas of students' competence that should be assessed by authentic assessments, namely attitudes, knowledge, and skills. The types of authentic assessment that could be used to assess students' skills are performance, project, and portfolio. This study aims at describing the implementation of authentic assessment to measure students' English productive skills based on 2013 Curriculum at the eighth grade of a pilot school--State Junior High School 1 Ungaran (SJHS1U) in the academic year 2015/2016, explaining the problems the teachers encountered in implementing it, and explaining the solution used by the teachers to overcome those problems. The data were collected through interviews, class and document observations, were validated by triangulation of sources and analysed by using the flow model of Miles and Hubberman (1984). The results of the study revealed that the English teachers of the school have implemented the authentic assessment to measure students' English productive skills. In doing so, the teachers asked the students to describe picture cues and retell the story as the performance assessments, to write a text for the portfolio assessment and to produce a comic for the project assessment. However, the implementation has not been conducted properly yet.
\end{abstract}

Keywords: authentic assessment; English productive skills; 2013 Curriculum

In 2013, the Indonesian Ministry of Education and Culture published the 2013 Curriculum to replace the implementation of School-Based Curriculum. One of the significant changes in 2013 Curriculum is the use of new method of assessment. Based on the regulation of the Minister of Education and Culture No. 81a, year 2013 about the implementation of 2013 Curriculum, teachers are required to implement authentic assessments as the method of assessing the students' competence. Moreover, according to the regulation of the National Minister of Education and Culture number 104 year 2014 on assessment system, teachers are expected to assess students' skills using performance, project, and portfolio assessments.

The implementation of those types of authentic assessments are quite challenging for English teachers. Based on the preliminary research, time limitation and scoring complexity are the assessments' main obstacles. Another difficulty is related to the management of classroom assessment activities due to the huge student population.

Some investigations on the implementation of authentic assessment have been conducted by previous researchers. Trisanti (2014) conducted a research on the teacher's perspective on the implementation of authentic assessment of 2013 Curriculum. It was described in details that teacher still had limited understanding about 2013
Curriculum. Teacher also thought that the implementation of authentic assessment did not run effectively because of the complex procedure and the class condition. Unfortunately, this study only discusses about the English teachers' perspective of the term authentic assessment so that it does not reflect what really happens on the site. Al Fama (2015), who conducted a study focusing on the implementation of authentic assessment in teaching writing, found that the teachers' knowledge and their experience influenced the implementation of the assessment. The teacher who had sufficient knowledge of the nature and types of authentic assessments implemented it properly. Appropriately employed, authentic assessments could provide feedback on a student's learning to encourage further development. It could improve students' knowledge, deep understanding, problem-solving skills, social skills, and attitudes which could be used in the simulation of a real-world situation. Although this study has depicted the implementation of authentic assessment on the site, it only focuses on one English productive skill - writing skill.

Different from the previous studies, the present study focuses on the implementation of authentic assessments to measure both students' English productive skills -- speaking and writing based on 2013 Curriculum. Conducted at SJHS1U, the school is considered to be the most credible junior high 
schools throughout Semarang regency and chosen by the government as a pilot school of 2013 Curriculum implementation since almost all teachers have got the training on the curriculum. This condition is considered ideal for providing accurate data, which reflects the real situation of the assessment's implementation.

On the basis of the aforementioned background, this study aims at describing the implementation of authentic assessment to measure students' English productive skills of the eighth graders of SJHS1U in the academic year 2015/2016, elaborating the difficulties in implementing it and the solution used by the teachers to overcome those difficulties.

\section{Authentic Assessment}

Authentic assessment is multiple forms of assessment that reflect student learning, achievement, motivation and attitudes on instructionally-relevant classroom activities (O’Malley \& Pierce, 1996). Particularly, according to the regulation of the Minister of Education and Culture No. 81, year 2013 about the implementation of 2013 Curriculum, an authentic assessment is an assessment which significantly focuses on measuring student's learning process dealing with their behavior, knowledge and skill. Accordingly, teachers are required to assess students' skills using performance, project, and portfolio assessments. Performance assessment is an assessment which is conducted by observing student's activities in doing particular activity; portfolio assessment is defined as a continuous assessment process based on a set of information that shows the development of students competence in a given period of time; while project assessment is an integrated unit of works which cannot be finished at a given time; it requires the students to do a series of tasks resulting on specific product or data (the regulation of the Minister of Education and Culture no. 104, year 2014).

\section{Designing and Scoring Authentic Assessment}

To implement the authentic assessment, there are some crucial points that teachers have to prepare. First of all, they have to be able to design an authentic assessment and learning objectives as suitable as possible for the students. Barker (1993) suggested to following eight steps in planning and designing authentic assessment: 1) building a team, 2) determining the purpose of the authentic assessment, 3) specifying objectives, 4) conducting professional development on authentic assessment, 5) collecting examples of authentic assessment, 6) adapting the existing authentic assessment or developing a new one, 7) trying out the assessment, and 8) reviewing the assessment.

In addition, another important point which should be provided is the scoring instrument. The authentic assessment is scored by using a rubric, rating scales, and a checklist (Nitko, 1983). A rubric is a scoring guide consisting of specific preestablished performance criteria, used in evaluating student works on authentic assessments (Mertler, 2001). There are two types of rubrics: holistic and analytic. A holistic rubric requires a teacher to score the overall process or product as a whole, without judging the component parts separately. Whereas in an analytic rubric, the teacher scores separate, individual parts of the product or performance first, then sums the individual scores to obtain a total score (Nitko, 1983). Nitko further suggested that there are three types of rating scales namely a numerical rating scale, a graphic rating scale, and a descriptive graphic scale that will serve the teacher well for most purposes. A checklist consists of a list of specific behaviors, characteristics or activities or a place for marking whether or not each is present. Teacher may use a checklist for assessing procedures students use, products students produce, or behaviors students exhibit.

\section{Types of Authentic Assessment}

O’Malley and Pierce (1996) mention three types of authentic assessment namely performance assessment, portfolios, and students-self assessment. Similar to those above, the 2013 Curriculum suggests three types of authentic assessment: performance, port-folio, and project assessments.

In reference to the regulation of the minister of education and culture number 81a year 2013, a performance assessment is an assessment which is conducted by observing student's activities in doing particular thing; a portfolio assessment is a purposeful collection of student's work that is intended to show the progress over time (O'Malley $\&$ Pierce, 1996). According to Gotlieb (1995), there are some steps in implementing a portfolio assessment in the classroom activities. Those steps are: 1) the teacher should explain to the students that portfolio will give benefits for both teacher and students; 2) together with the students, the teacher decides the samples of portfolio tasks; 3 ) the tasks are collected and organized into a special folder; 4) every task is identified based on the date of submission so that the teacher can track the students' progress during a given time; 5) the teacher determines the criteria of scoring with students; 6) the teacher may ask students to check their own work and at the same time help them how to assess and improve the task; 7) if the students get a low score on the assessment, the teacher may give them opportunity to improve their works within a particular time; 8) finally, each of student work is collected into one file as the portfolio assessment archive.

The next authentic assessment chosen by the teachers was the project assessment. It is an integrated unit of works which cannot be finished at a time (Phillips, Burwood, \& Dundorf, 1999). A 
project requires the students to do a series of task which will result in a specific product or data.

\section{Authentic Assessment of Speaking}

Assessments of speaking should focus on student's ability to interpret and convey meanings for authentic purpose in interactive context. Teachers need to use assessment tasks which are as authentic as possible in a classroom setting. This means (1) using authentic language in speaking, (2) setting real world task, and (3) giving the students opportunities to use language in situation based on everyday life. It is important to expose students to authentic language and help them work out strategies for dealing with less than total comprehension (Porter \& Roberts, 1987). O'Malley and Pierce (1996) provide some steps in preparing speaking assessment: 1) identifying purpose, 2) planning for assessment, 3) developing scoring procedures, 4) setting standard, 5) selecting assessment activities, and 6) recording information.

\section{Authentic Assessment of Writing}

Unlike other skills, writing cannot be assessed by using a conventional method like a multiple choice or true-false item test. A teacher can only know the students' writing competence by checking their work in detail. Accordingly, an authentic assessment is seen as the most appropriate method in assessing students writing skill.

The following are the steps in assessing students writing by using authentic assessment proposed by O'Malley and Pierce (1996): 1) selecting topic that is appropriate for the students, 2) selecting rubrics students can use, 3) sharing rubrics with the students, 4) identifying bench-mark papers, 5) reviewing how students write not just what they write, 6) having a conference with the students on their writing results.

\section{METHOD}

Since the present study concerned with the processes of an authentic assessment implementation, a descriptive qualitative study design was employed. The subjects of the study were two English teachers of the eighth grade in SJHS1U. Meanwhile, the object of the study was the process of implementing authentic assessment in the form of practice, project and portfolio to measure the subjects' English productive skills.

Collecting data is the essential part in conducting a research. In this research, interviews, class observations and document observations were applied to obtain the data. The interview employed in this research was semi-structured since further discussion and questioning could go further than what was listed in the interview questions. Two sets of interviews were conducted to the curriculum coordinator and the English class teachers. The interview with the curriculum coordinator was to find out the general description of the implementation of authentic assessment of 2013 Curriculum, and the way she coordinates the teachers and manages the assessment implementation. The list of questions of the interview is attached.

In terms of document observation, with the permission of the curriculum coordinator and English teachers all documents were collected and observed. They were the references used by the teacher in implementing the assessment. The documents were lesson plans, scoring rubrics and students' products.

As for class observation, it was conducted to obtain the teaching and learning activities in the classroom especially on how the teacher implemented the authentic assessment to measure the students' English productive skills. The researchers decided to be non-participative observers who were not actively involved in the teaching and learning process to keep the class activities run naturally.

After the data were obtained, they were analyzed by using three steps of Miles and Hubberman's (1984) analysis model, namely data reduction, data display and conclusion. The researchers transcribed the interview results and categorized the data based on their categories. Meanwhile, the data of the class observation and document observation were typed and categorized respectively. Then all the data were reduced and the important items remained. The following step was displaying the analyzed data. They were presented and interpreted before the conclusion was drawn.

To achieve the validity, strength, and interpretative potential of a study, to decrease investigator bias and to provide multiple perspectives, this study used the triangulation of sources. The data were obtained from different sources of information. Thus the triangulation in this study had been done by comparing the data obtained from the interview, class observation and document observation. The data from the different sources had been cross-checked. Some irrelevant data was eliminated to meet the objectives - the answers of the research questions.

\section{RESULTS AND DISCUSSIONS}

The findings of the class observation, interview and document observation were interpreted specifically on three scopes to gain the conclusions. The scopes were the implementation of authentic assessment to measure students' English productive skills based on 2013 Curriculum, the teachers' difficulties in implementing it and the teachers' solution to overcome those difficulties. 
The Implementation of the Authentic Assessments

The implementation consisted of three parts, namely designing the authentic assessment, implementing it, scoring students' product and giving feedback to the students. It was found that the teachers used six steps out of eight steps suggested by Barker (1993) in planning and designing authentic assessment. The results of the interviews revealed that they build a team consisting of the curriculum coordinator and themselves to discuss how to implement authentic assessment to the students. The results of document observation on their lesson plans showed that they determined the purpose of the authentic assessment and specified the objectives. Furthermore, from the results of the class observation, it was found that the teachers conducted professional development on the authentic assessment and collected examples of them. Unfortunately they did not do two last steps suggested by Barker (1993), the trying out and reviewing the assessment before implementing it to the students because they did not have enough time to do it. Consequently, there were several criteria that had not been covered in the teachers' scoring rubric.

In addition, the teachers chose to use analytic rubric in scoring their students' authentic assessment because formative feedback is the goal. Table 1 and Table 2 show the rubric of speaking skill and writing skill assessments respectively.

Table 1. Rubric for assessing speaking skills

\begin{tabular}{lclc}
\hline Aspect & Information & Score \\
\hline Pronunciation & - & Very clear so easy to understand. & $22-25$ \\
& - & Easily understood despite the influence of the mother tongue can be detected. & $18-21$ \\
& - & There are pronunciation problems so that listeners need full concentration. & $14-17$ \\
& - & There are serious pronunciation problems that cannot be understood. & $10-13$ \\
\hline Grammar & - & No or few grammatical errors. & $22-25$ \\
& - & Sometimes there is a mistake but it does not affect the meaning. & $18-21$ \\
& - & Often make mistakes making the meaning hardly comprehensible. & $14-17$ \\
& - & Severe solecism that it could not be understood. & $10-13$ \\
\hline Vocabulary & - & & $22-25$ \\
& - & Using the appropriate vocabulary and expressions. & $18-21$ \\
& - & Often using inappropriate vocabularies. & $14-17$ \\
& - & Vocabulary is very limited so that the conversation cannot be happening. & $10-13$ \\
\hline Fluency & - & & $22-25$ \\
& - & Fery fluent. & $18-21$
\end{tabular}

After the rubrics were prepared by the teachers, they conducted the performance, project, and portfolio assessments in assessing student's English productive skills.

For assessing speaking skill, the teachers used a performance assessment. O'Malley and Pierce (1996) suggest that there are several kinds of performance assessment: oral interviews, picturecued descriptions or stories, radio broadcasts, video clips, information gap, story or text retelling. The teachers asked the students to do oral presentations by describing picture cues and retelling story or text. Before conducting the assessment, they held some preparations. Slightly different from O'Malley and Pierce's (2006) steps in preparing speaking assessment, the teachers only conducted five preparation steps which were identifying purpose, planning for assessment, developing scoring procedures, setting standard and selecting assessment activities. They did not do the last preparation namely recording information. Ideally, teachers had to document the results of the assessment. This is important to inform the students about their progress in the learning process. The information gathered from the record can be used not only to inform instruction and assessment but also to communicate with the students on how they are doing. It can also provide feedback to the teacher on the effectiveness of teaching materials and activities.

In implementing portfolio assessment the teachers asked the students to make a written text based on the theme they discussed in every chapter. This is in line with Kern (2000) who suggests that a portfolio is typically used to assess writing skill.

The first English teachers made a good English worksheet containing three columns. The first column was for student's portfolio work, the second column was for the revision of student's portfolio work, and the third was the score column. Unfortunately in the student's portfolio work, there was no revision at all. The teacher said that she did not have enough time to give complete feedbacks to the students. She only gave several simple 
comments, such as good, excellent, great, etc. Therefore the students did not know what to revise in their writing. Ideally the teacher gives complete feedbacks on the writing content, grammar, and structure. If the teacher does not have time in doing this, she can ask the students to do peer-assessment or peer-editing in checking their writing structure. So the teacher only focuses on checking the students' grammar and content.

Table 2. Rubrics for assessment of writing skills

\begin{tabular}{|c|c|c|}
\hline Aspects & Information & Score \\
\hline Writing & Very original & 5 \\
\hline \multirow{4}{*}{ Authenticity } & - Original & 4 \\
\hline & - Fairly Original & 3 \\
\hline & - $\quad$ Less Original & 2 \\
\hline & - $\quad$ Not Original & 1 \\
\hline \multirow{5}{*}{$\begin{array}{l}\text { Content } \\
\text { accordance } \\
\text { with the title }\end{array}$} & Content is very in accordance with the title & 5 \\
\hline & - Content is in accordance with the title & 4 \\
\hline & - Content is fairly in accordance with the title & 3 \\
\hline & - Content is in less accordance with title & 2 \\
\hline & - Content is not in accordance with the title & 1 \\
\hline \multirow{5}{*}{$\begin{array}{l}\text { Text } \\
\text { harmony }\end{array}$} & Harmony of text is very precise & 5 \\
\hline & - $\quad$ Harmony of text is precise & 4 \\
\hline & - Harmony of text is quite precise & 3 \\
\hline & - Harmony of text is less precise & 2 \\
\hline & - $\quad$ Harmony of text is not precise & 1 \\
\hline \multirow{5}{*}{$\begin{array}{l}\text { Vocabulary } \\
\text { selection }\end{array}$} & Vocabulary selection is very appropriate & 5 \\
\hline & - Vocabulary selection is appropriate & 4 \\
\hline & - Vocabulary selection is quite appropriate & 3 \\
\hline & - Vocabulary selection is less appropriate & 2 \\
\hline & - Vocabulary selection is inappropriate & 1 \\
\hline \multirow{5}{*}{$\begin{array}{l}\text { Grammar } \\
\text { options }\end{array}$} & - $\quad$ Selection of grammar is very proper & 5 \\
\hline & - $\quad$ Selection of grammar is proper & 4 \\
\hline & - $\quad$ Selection of grammar is quite proper & 3 \\
\hline & - $\quad$ Selection of grammar is less proper & 2 \\
\hline & - $\quad$ Selection of grammar is improper & 1 \\
\hline Vocabulary & Vocabulary writing is very precise & 5 \\
\hline \multirow[t]{4}{*}{ Writing } & - Vocabulary writing is precise & 4 \\
\hline & - Vocabulary writing is quite precise & 3 \\
\hline & - Vocabulary writing is less precise & 2 \\
\hline & - $\quad$ Vocabulary writing is not precise & 1 \\
\hline Writing & Writing is neat and easily readable & 5 \\
\hline \multirow[t]{3}{*}{ Tidiness } & - Writing is untidy but easily readable & 4 \\
\hline & - Writing is neat but not easily readable & 3 \\
\hline & - Writing is untidy and hardly readable & 2 \\
\hline
\end{tabular}

However, the second teacher did not make a worksheet for English students' portfolio and was still confused in documenting the students' portfolio. Thus, after the students had finished their portfolio assignment, they collected them to the teacher. After scoring them and giving them feedbacks, the teacher returned the portfolio works to the students. Hence, the teacher did not have the documentation of the students' portfolio.

In brief, portfolio assessment requires students together with the teachers to determine what topic and kind of work they will do in the form of writing and the duration of time the assignment can be completed. Within this duration, teachers supervise and observe students' progress and if there is a problem, then both teachers and students solve it together and do some improvements. At the end of the duration, students submit their work which will be evaluated by the teacher.
Nevertheless, the research shows that the teachers determined the topic and kind of writing work by themselves. They only gave comments in the students' work without discussing together with the students to do some improvement. Therefore, it only seems a scrapbook or a collection of students' works. Whereas, according to Damiani (2004) a portfolio is not simply a scrapbook or collection of all of students' works. The works put into portfolio are carefully and deliberately selected so the collection as a whole accomplishes its purpose. Here, a teacher should give students the opportunity to choose and decide what tasks they are going to submit. This is important to stimulate students to recognize their strength and weaknesses.

Another finding is related to the steps used by the teachers in authentic assessing writing. As suggested by O'Malley and Pierce (1996), there are six steps to conduct by the teachers; yet, they only did the three first steps: selecting a topic appropriate 
for the students, selecting rubric students can use and sharing rubrics with the students. They did not do the three last steps namely identifying benchmark papers, reviewing students writing structure not just their writing content, and conferencing to discuss writing with the students. They should identify benchmark papers to communicate what a good writing is to the students. Furthermore, the teachers should review how students write because both teacher and students will obtain a better understanding in the writing processes. Finally, the teacher should have a conference with the students to discuss their writing because occasional writing conferences provide excellent opportunities to ask students key questions about their writing processes and to provide students with personal feedback on their writing.

In implementing authentic project assessment the first teacher assigned the students to produce a comic. First, the teacher told the students that they would have a project of making a comic. Then the students were divided into group of three or four. In their groups they discussed the idea of the story and the teacher asked them to make the concept of the comic. She told them to make the outline of the comic in the form of a summary of every page. Having completed the comic concept, the students submitted it to the teacher. Then, the teacher gave the feedback and she returned the concept to the students. Finally she told the students to make the complete comic based on their corrected concept and submitted it the following month. This finding is in line with Pavlou and Ioannou-Georgiou (2003) who stated that project is not necessarily being done at school. Some projects may result better when it is done outside the school. This kind of work is known as a take home task which can be done by students outside the school after they consult the work with the teacher.

Even though the students finished the project at home, in every meeting the teacher always monitored how far the students had done with the project and made a control card. The function of the control card was to control what the students did in the group. For example in making the comic project, the students divided the project into all members of the group; member A made four pages (1 to 4); member $\mathrm{B}$ pages 5 to 8 ; member $\mathrm{C}$ pages 9 to 12 , and so on. Finally the teacher scored the students' products based on the scoring rubric they had made before. After scoring students products, the teacher gave the students the feedback. But, she only gave the general feedback such as excellent, great and good. This is not in line with Wiggins (1993) who stated that the important outcome of authentic assessment has to do with providing feedback to the students related to significant objectives. Many teachers erroneously believe they are providing feedback with test scores and comments such as "good work," "vague," and "unclear." What students want and need is information about their performances and the revision to make. Students need information that will help them self-assess and self-correct so that assessment becomes integrated with the learning experience. Sometimes the teachers add the general comments with instructions such as "add the content" and "add the supporting sentences" but they are still general and cannot make the students know their strength and weakness in the topic being discussed. Feedbacks should help students see and revise their products (writing) themselves.

\section{The Teachers' Difficulties in Implementing the Authentic Assessment}

The process of implementing authentic assessments in English instruction based on curriculum 2013 at SJHS1U still did not run effectively. The English teacher seemed to encounter some difficulties in applying portfolio, performance, and project assessment in assessing students' productive skills in reference to scoring guidance for junior high school.

Similarly, the assessment method was quite complex and time consuming so that teachers were confused and shifted their focus from teaching to mostly assessing. Above all, managing the classroom assessment activities and scoring the results of the students' tasks and giving students feedback were complicated duties to do since the time allotted was only four credit hours per week.

The findings are in line with O'Malley and Pierce (1996), stating that authentic assessment is likely to encounter three difficulties concerning the purpose, the fairness and the grading process. The purpose of the assessments affects whether or not the students receive special language-based instruction, the type of instruction, and the duration over which the instruction held. Additionally, the purpose of the assessment determines the design of the assessment. With limited sources, time and partners, the teachers were not able to develop the assessment appropriately. Particularly, it was found that every type of the authentic assessments had different problems in the process of its enactment. In implementing the performance assessment, it was hard to encourage students' confidence to do oral presentations and took long scoring time. The problem of portfolio assessment encountered by the teachers was mostly dealing with complicated binder management. While the problem of implementing project assessment was related to ensure that the students were fully aware of their responsibility to do their task. Moreover, the teachers of SJHS1U also have other problems dealing with the class size. According to Kerr (2011) large student number limited the assessment methods available for them and the number of assessment that could be conducted. Because of the excessive number of students in their classes, it was 
quite difficult for the teachers to manage the performance tasks. The allotted time was inadequate to cover all students to perform in one meeting.

The Teachers' Solution to the Difficulties in Implementing the Authentic Assessment

The English teachers of SJHS1U obviously realized that they were fully responsible of implementing authentic assessments effectively. Nevertheless, they still encountered many difficulties in administering them.

To solve the problems, the teachers conducted some techniques or tricks in the process of learning and assessing. It was found that the first teacher used a spontaneous speaking test. Prior to the test, she did not tell her students that they would be assessed. Based on her experience, if the students were told in advance that they would be assessed, they would refuse to speak in front of the class and kept saying that they were not ready yet.

On the other hand the second teacher, gave an extra score for the student being the first speaker in the speaking test. Moreover, she reduced the scoring rubric from five criterion to 4 criterion. It was done to give a better focus on the student's performance.

In overcoming her difficulty in implementing portfolio assessment, the first teacher applied peer editing. Thus the students correct their friends' portfolio assignment. In this case she only asked the students to correct the writing structure, such as the use of full stop, coma, and capital letter. Therefore she could focus more on the content of the portfolio assignment results.

The solution that had been done by the first teacher to overcome her problem in implementing the project assessment was by means of a control card. The card functions as control of what the students did in the group in their process of writing.

\section{CONCLUSION}

In conclusion, the English teachers at the eighth grade of SJHS1U have implemented the authentic assessment to measure students' English productive skills. However, it has not been conducted properly in designing the authentic assessment, implementing the authentic assessment and in scoring students' products as well as in giving students feedback. In implementing the authentic assessment, the teachers asked the students to do oral presentation in describing picture cues and retelling story for the performance assessment. They asked the students to write a text as the portfolio assessment, and assigned the students to produce a comic as the project assessment. Particularly, it was found that each type of the assessment has different problems in the process of its enactment. In implementing performance assessment, it was hard to encourage students' confidence in doing oral presentation and took much time on scoring. The problem related to portfolio assessment was more on dealing with complicated binder management. While in project assessment, the problems the teachers encountered was ensuring the students to accomplish their task responsibly. The teachers did some techniques or tricks in overcoming the problems, such as implementing spontaneous speaking test, encouraging the students through giving extra score for the first speaker in performance assessment, reducing the scoring rubric from 5 criterion to 4 in order to focus on students performance better, and using a control card in assessing student's project .

\section{REFERENCES}

Al Fama, Y. A. A. M. (2015). The implementation of authentic assessment in teaching writing (Unpublished master's thesis). Universitas Sebelas Maret Surakarta, Surakarta, Indonesia.

Barker, E. L. (1993). Questioning the technical quality of performance assessment. The School Administrator 50(11), 12-16.

Damiani, V. B. (2004). Portfolio assessment in the classroom. National Association of School Psychologists, 301(1), 3-132.

Gottlieb, M. (1995). Nurturing student learning through portfolios. TESOL journal, 5(1), 1214.

Kementerian Pendidikan dan Kebudayaan Republik Indonesia. (2013). Peraturan Menteri Pendidikan dan Kebudayaan No. 81a tentang Implementasi Kurikulum 2013. The Ministry of Education and Culture, Jakarta, Indonesia.

Kementerian Pendidikan dan Kebudayaan Republik Indonesia. (2014). Peraturan Menteri Pendidikan dan Kebudayaan No. 104 tentang Penilaian Hasil Belajar. The Ministry of Education and Culture, Jakarta, Indonesia.

Kern, R. (2000). Literacy and language teaching. New York: Oxford University Press.

Mertler, C. A. (2001). Designing scoring rubrics for your classroom. Practical Assessment, Research \& Evaluation, 7(25), 1-10.

Miles, M. B., \& Huberman, M. (1984). Qualitative data analysis: A sourcebook of new methods. London: Sage Publication, Inc.

Nitko, A. J. (1983). Educational test and measurement: An introduction. New York: Harcourt Base Jovanovich.

O’Malley, J. M., \& Pierce, L. V. (1996). Authentic assessment for English language learners: practical approaches for teachers. Massachusetts: Addison Wesley Publishing Company.

Pavlou, P., \& Ioannou-Georgiou, S. (2003). Assessing young learners. Oxford: Oxford University Press. 
Rukmini and Saputri, The authentic assessment to measure students'...

Phillips, D., Burwood, S., \& Dunford, H. (1999). Projects with young learners. New York: Oxford University Press.

Porter, D., \& Roberts, J. (1987). Authentic listening activities. In M. H. Long, \& J. C. Richards, (Eds.), Methodology in TESOL: A book of readings (pp. 177-187). New York: Newbury House.
Trisanti, N. (2014). English teacher's perspective on authentic assessment implementation of curriculum. Proceedings of the $61^{\text {st }}$ TEFLIN International Conference 2014. Sebelas Maret University Press, Surakarta, Indonesia.

Wiggins, G. P. (1993). Assessing students' performance. San Francisco: Jossey Bass Publisher. 


\section{Appendix}

The Result of Class Observation

\begin{tabular}{|c|c|c|c|c|c|c|}
\hline \multirow[t]{2}{*}{ No. } & \multirow[t]{2}{*}{$\begin{array}{c}\text { Kinds of } \\
\text { Assessment }\end{array}$} & \multirow[t]{2}{*}{ Activity } & \multicolumn{2}{|c|}{$\begin{array}{l}\text { The } 1^{\text {st }} \\
\text { teacher }\end{array}$} & \multicolumn{2}{|c|}{$\begin{array}{l}\text { The } 2^{\text {nd }} \\
\text { teacher }\end{array}$} \\
\hline & & & Yes & No & Yes & No \\
\hline \multirow[t]{5}{*}{1.} & \multirow[t]{5}{*}{$\begin{array}{l}\text { Performance } \\
\text { Assessment }\end{array}$} & $\begin{array}{l}\text { f. The teacher gave an } \\
\text { understanding to the students } \\
\text { about how they would be } \\
\text { scored (the scoring rubric). }\end{array}$ & V & & & V \\
\hline & & $\begin{array}{l}\text { g. The teacher always checked the } \\
\text { availability of the materials to } \\
\text { support the students' } \\
\text { performance. }\end{array}$ & V & & & V \\
\hline & & $\begin{array}{l}\text { h. The teacher scored the } \\
\text { students' performance based on } \\
\text { the scoring rubric in her lesson } \\
\text { plan. }\end{array}$ & & $\mathrm{V}$ & V & \\
\hline & & $\begin{array}{l}\text { i. The teacher documented the } \\
\text { students' performance. }\end{array}$ & & $\mathrm{V}$ & V & \\
\hline & & $\begin{array}{l}\text { j. The teacher gave feedback in } \\
\text { every students' performance }\end{array}$ & & $\mathrm{V}$ & V & \\
\hline \multirow[t]{4}{*}{2.} & \multirow[t]{4}{*}{$\begin{array}{l}\text { Portfolio } \\
\text { Assessment }\end{array}$} & $\begin{array}{l}\text { f. The teacher gave the students } \\
\text { the opportunity to choose and } \\
\text { decide what tasks they were } \\
\text { going to submit as their } \\
\text { portfolio. }\end{array}$ & & V & & V \\
\hline & & $\begin{array}{l}\text { g. The teacher asked the students } \\
\text { to note their portfolio result as } \\
\text { their reflection. }\end{array}$ & & $\mathrm{V}$ & & V \\
\hline & & $\begin{array}{l}\text { h. The teacher documented the } \\
\text { students' portfolio. }\end{array}$ & V & & & V \\
\hline & & $\begin{array}{l}\text { i. The teacher gave continuously } \\
\text { feedback to the students' }\end{array}$ & & & & \\
\hline
\end{tabular}




\begin{tabular}{|c|c|c|c|c|c|c|}
\hline & & $\begin{array}{l}\text { portfolio (how far they } \\
\text { achieved the learning } \\
\text { objectives, how their strengths } \\
\text { and weakness in mastering the } \\
\text { lesson material and how they } \\
\text { could revise their portfolio). } \\
\text { j. The teacher asked the students } \\
\text { to give their identity their } \\
\text { portfolio. }\end{array}$ & $\mathrm{V}$ & $\mathrm{V}$ & $\mathrm{V}$ & $\mathrm{V}$ \\
\hline \multirow[t]{5}{*}{3.} & \multirow[t]{5}{*}{$\begin{array}{l}\text { Project } \\
\text { Assessment }\end{array}$} & $\begin{array}{l}\text { f. The teacher gave an } \\
\text { understanding to the students } \\
\text { about how they would be } \\
\text { scored (the scoring rubric). }\end{array}$ & $\mathrm{V}$ & & & $\mathrm{V}$ \\
\hline & & $\begin{array}{l}\text { g. The teacher assessed the } \\
\text { students during planning, } \\
\text { processing and reporting their } \\
\text { project. }\end{array}$ & & $\mathrm{V}$ & & $\mathrm{V}$ \\
\hline & & $\begin{array}{l}\text { h. The teacher monitored the } \\
\text { students in finishing their } \\
\text { project and gives them } \\
\text { feedback in every section of } \\
\text { their project. }\end{array}$ & $\mathrm{V}$ & & & $\mathrm{V}$ \\
\hline & & $\begin{array}{l}\text { i. The teacher documented the } \\
\text { students' project. }\end{array}$ & $\mathrm{V}$ & & & $\mathrm{V}$ \\
\hline & & $\begin{array}{l}\text { j. The teacher gave feedback to } \\
\text { your students' project. }\end{array}$ & $\mathrm{V}$ & & & $\mathrm{V}$ \\
\hline
\end{tabular}

\section{Questions of Teachers' Interview}

1) As we know that, the Ministry of Education and Culture have published several regulations deal with the implementation of 2013 Curriculum. Which regulations did you/ this school use as the references in designing and implementing authentic assessment?

2) Was there any other guidance that used by the school as a reference in designing and implementing authentic assessment?

3) In practice, did you always conduct the authentic assessment based on the lesson plan which you have written? Or was there any modification and adaptation in its implementation?

4) Did you always implement authentic assessment in the form of performance, project and portfolio to measure the students' English productive skills in the end of every chapter (basic competence)?

5) Did you give an understanding to your students about how they would be scored (the scoring rubric) before you do the performance, portfolio and project assessment?

6) In practice, was there any criterion which has not been covered in your scoring rubric? If yes, what would you do? Did you adapt the criterion in your rubric or still use the exits scoring rubric? 


\section{Performance Assessment}

a) How did you give the time allotment for performance assessment?

b) Thus, was there any difference scoring rubric between the students who perform today and those who perform next week?

c) Did you always check the availability of the materials to support the students' performance?

d) How did you document the students' performance?

e) How did you give feedback to your students?

f) What difficulties did you face in implementing performance assessment?

g) What were the solutions that you have been done to overcome those difficulties?

\section{Portfolio Assessment}

a) How did you give the time allotment for performance assessment?

b) How did you document the students' portfolio?

c) Did the students note their portfolio result?

d) What kinds of identity did the students need in their portfolio?

e) How did you give feedback to your students?

f) What difficulties did you face in implementing performance assessment?

g) What were the solutions that you have been done to overcome those difficulties?

\section{Project Assessment}

a) How did you give the time allotment for project assessment?

b) Did you always assess the students during planning, processing and reporting their project?

c) Did you always monitor the students in finishing their project and give them feedback in every section of their project?

d) How did you document the students' project?

e) How did you give feedback to your students' project?

f) What difficulties did you face in implementing project assessment?

g) What were the solutions that you have been done to overcome those difficulties? 